\title{
Penggunaan Instrumen Permainan Bendera dalam Meningkatkan Prestasi Belajar Pendidikan Agama Islam
}

\author{
Hasan Basri \\ SDN 182/IX Ujung Tanjung Kabupaten Muaro Jambi \\ Correspondence email: basrie128@gmail.com
}

\begin{abstract}
Abstrak. Pendidikan Agama Islam pada jenjang Sekolah Dasar diperkenalkan kepada siswa tentang aspek-aspek Agama Islam itu sendiri, mulai mengenal aspek-aspek rukun Islam dan iman kepada Allah sampai dengan kepada Qadha dan Qadar, dan mempelajari Al-Qur'an. Dalam kehidupan sehari-hari berperilaku terpuji serta menghindari perilaku tercela. Memperkenalkan dan menjalankan rukun Islam yang dimulai dari bacaan dua kalimat syahadat sampai mengetahui tata cara pelaksanaan ibadah haji. Menceritakan kisah orang-orang tercela dalam kehidupan sehari-hari serta menceritakan kisah-kisah para nabi dan memberikan teladan dari kisah-kisah tersebut. Dari kesemua itu akan menjadikan para siswa sebagai bekal nantinya. Apabila di sampaikan dengan cara yang kurang konvensional maka aspek itu akan sukar dicerna oleh siswa. Berdasarkan uraian diatas maka untuk itu perlu di lakukan sebuah penelitian. Maksud dan tujuan dari penelitian ini untuk meningkatkan hasil belajar Pendidikan Agama Islam dengan menggunakan Instrumen Permainan Bendera pada pelajaran Agama Islam. Penelitian ini dilaksanakan dalam dua siklus. Dalam penelitian ini yang menjadi partisipan adalah siswa kelas I SDN 182/IX Ujung Tanjung. Jumlah siswa sebanyak 29 anak. Lembar observasi aktifitas guru, aktifitas siswa dan tes yang digunakan dalam metode pengumpulan data. Untuk mendapatkan data hasil belajar. Hasil dan data yang diperoleh dari Siklus I dan Siklus II menekankan bahwa Dengan menggunakan instrumen Permainan Bendera, hasil dan data yang diperoleh dari Siklus I dan Siklus II menyatakan bahwa ditemukan sebuah peningkatan hasil belajar yang sangat signifikan dengan jumlah nilai baik dan nilai amat baik dari yang awalnya hanya $48,1 \%$ menjadi sebesar $92,8 \%$.
\end{abstract}

Kata Kunci: Bendera; Hasil Belajar; Pendidikan; Permainan

Abstract. Islamic education at the elementary school level is introduced to students about aspects of the Islamic religion itself, getting to know aspects of the pillars of Islam and faith in Allah down to Qadha and Qadar, and studying the Qur'an. In everyday life behave praiseworthy and avoid disgraceful behavior. Introducing and carrying out the pillars of Islam starting from reading two sentences of the creed to knowing the procedures for carrying out the pilgrimage. Telling stories of disgraceful people in everyday life and telling stories of the prophets and providing examples of those stories. Of all that will make the students as provisions later. If it is conveyed in a less conventional way, it will be difficult for students to digest that aspect. Based on the description above, it is necessary to do a study. The aims and objectives of this study are to improve learning outcomes of Islamic Religious Education by using Flag Game Instruments in Islamic studies. This research was conducted in two cycles. In this study, the participants were grade I SDN 182 / IX Ujung Tanjung. The number of students is 29 children. Teacher activity observation sheets, student activities and tests used in the data collection method. To get data on learning outcomes. The results and data obtained from Cycle I and Cycle II emphasize that by using the Flag Game instrument, the results and data obtained from Cycle I and Cycle II state that a very significant increase in learning outcomes is found with a number of good scores and very good scores from those initially only $48.1 \%$ to $92.8 \%$.

Keywords: Education; Flag; Games; Learning Outcomes

\section{PENDAHULUAN}

Berdasarkan pengalaman selama mengajar siswa Kelas I jenjang Sekolah Dasar untuk Pendidikan Agama Islam dijumpai siswa masih terlihat mengalami kesulitan, salah satunya adalah sulitnya siswa dalam menghafal surat-surat yang terdapat dalam Al-Qur'an. Metode hafalan yang sebelumnya sudah dipraktekkan mempunyai banyak kekurangan, sehingga siswa kesulitan dalam mengurutkan dan melafalkannya. Selain itu, faktor lainnya, masih banyak siswa yang belum lancar bahkan belum tahu cara membaca Al-Qur'an. Ini kemungkinan bisa disebabkan karena siswa belum pernah diperkenalkan kepada Al-Qur'an serta kegunaan dan fungsi hafalan surat-surat dalam menunaikan Sholat. Al Fatihah (2016) mengungkapkan prestasi belajar adalah tolak ukur dalam menentukan keberhasilan suatu pembelajaran. Tak terkecuali mata pelajaran Pendidikan Agama Islam. Terkait dengan hasil atau prestasi itulah sebagai peneliti bisa didapatkan bahwa tidak semua siswa memliki tingkatan atau taraf pemahaman yang baik mengenai suatu pelajaran. Dan dilain pihak tak hanya problem datang dari siswa tetapi menurut Nurlina, dkk (2014). Dalam kenyataan banyak sekali yang terjadi di lapangan tentang pembelajaran yang belum terlaksana sesuai dengan manajemen pengajaran karena sebagian guru masih belum dapat mengikuti prosudurm pengajaran yang telah ditetapkan dan tidak terlalu memahami tentang peranan manajemen dalam pengajaran. Maka daripada itu, sebuah solusi harus digunakan.

Untuk mengatasi permasalahan tersebut, perlu dilakukan penerapan pembelajaran melalui Permainan 
Bendera agar siswa mudah mempelajari dan mengingat surat-surat pendek Al-Qur'an yang akan meningkatkan hasil belajar. Setiap siswa seusia kelas I Sekolah Dasar selalu ingin bermain. Bermain merupakan sesuatu yang menyenangkan bagi siswa terutama yang berusia dini. Hampir tidak ada permainan yang membuat siswa tidak merasa senang. Bermain dapat terjadi lama-lama namun juga dapat ia lakukan sesaat atau sebentar. Bermain sangat penting bagi tumbuh kembang seorang anak. Bermain adalah salah satu cara dalam membantu pengembangan karakter dan berbagai aspek pada anak usia dini. Bermain merupakan kegiatan yang dilakukan berulang-ulang demi kesenangan. Piaget (1951) kemudian Freeman dan Munandar (1996). Bermain dapat membantu anak dalam mencapai perkembangan yang utuh, baik secara fisik, sosial, intelektual, moral dan emosional. Dananjaya (2012) menyarankan daur belajar pengalaman tentang bagaimana mengembangkan permainan. Berdasarkan daur belajar tersebut dikembangkan suatu permainan yang disebut Permainan Bendera. Permainan Bendera ini dikembangkan dan diberi sedikit senutuhan modifikasi dari instrumen yang digunakan, menjelaskan permainan bendera pintar ialah permainan yang dikolaborasikan antar membilang dengan sebuah alat berbentuk bendera yang telah dimodifikasi sesuai dengan kebutuhan, dimana disetiap bendera telah diberikan nomor dari 1-20. Untuk mengembangkan kemampuan membilang 1-20 pada anak usia dini melalui permainan.

Penelitian Permainan Bendera ini diberi sedikit perubahan untuk pelajaran Pendidikan Agama Islam, yaitu: (1) Membentuk kelompok belajar; (2) Memberikan kesempatan kepada perwakilan kelompok untuk mengambil Bendera sesuai urutan ayat; (3) Memberikan kesempatan kepada anggota kelompok untuk mengurutkan Bendera sesuai urutan ayat; (4) Memberikan kesempatan kepada anggota kelompok untuk membaca urutan ayat dengan keras; (5) Setelah dibacakan disusun di meja sebagai bahan untuk dihafalkan; dan (6) Siswa yang lebih mampu dapat memandu temannya. Penggunaan Permainan Bendera ini sendiri juga diteliti oleh Sulasmi (2014) didalam jurnalnya mengungkapkan, peserta didik melalui bermain dan belajar memberikan suasana lebih meriah, aktif dan berani tampil, yang berbeda dibandingkan dari metode yang dilakukan oleh guru sebelumnya. Tujuan penelitian tindakan kelas ini adalah untuk meningkatkan prestasi belajar siswa dalam mata pelajaran Pendidikan Agama Islam.

\section{METODE}

Dalam Penelitian ini metode yang digunakan menggunakan model penelitian Kemmis \& McTaggart dalam Nurmayanti, dkk (2017) yang memiliki 4 komponen yaitu: (1) Perencanaan; (2) Pelaksanaan, (3) Observasi, (4) Refleksi. Keempat komponen tersebut membentuk suatu siklus kemudian dalam pelaksanaanya membentuk lebih dari satu siklus yang mencakup keempat komponen tersebut. Salah satu model yang paling populer dan paling tepat dalam Penelitian Tindakan Kelas. Setelah semua persiapan matang langkah selanjutnya adalah perencanaan yang sudah dianalisis dan direvisi, pelaksanaan tindakan, pengamatan terhadap partisipan dan lingkungan sekitar, dan refleksi atas hasil data. Perlu dilakukan tindakan awal yang berupa identifikasi permasalahan, yang mana tindakan ini bisa dilakukan sebelum siklus I dengan sebuah tes permulaan penelitian ini mengambil tempat di SDN 182/IX Ujung Tanjung.

Dalam penelitian ini partisipannya adalah siswa Kelas I Semester Genap tahun pelajaran 2019/2020 yang mana siswa yang diambil pada kelas I berjumlah 20 orang terdiri dari 8 orang laki-laki, dan 12 orang perempuan. Adapun yang diambil menjadi instrumen dalam penelitian ini yang digunakan terdiri dari: lembar observasi untuk mengamati pelaksaanan guru dalam melakukan Permainan Bendera yaitu lembar observasi; untuk mengamati kegiatan dan aktifitas siswa saat mengikuti pembelajaran, yang digunakan untuk mengetahui peningkatan hasil belajar siswa terhadap materi yang dipelajari selama penelitian berlangsung yaitu dengan Permainan Bendera.

Teknik pengumpulan data yang digunakan adalah teknik observasi dan tes terulis. Dalam teknik pengumpulan data observasi, di mana peneliti melakukan pengamatan secara langsung ke objek penelitian untuk melihat dari dekat kegiatan yang dilakukan. Observasi menurut Riduwan dalam Ayudia, Suryanto dan Waluyo (2016). Tes Tulis yang digunakan berbentuk uraian. Tes tertulis bentuk uraian merupakan seperangkat soal yang berupa tugas, pertanyaan yang menuntut peserta didik untuk mengorganisasikan dan menyatakan jawabannya menurut kata-kata sendiri. Dan dapat berbentuk mengingat kembali, menyusun, mengorganisasikan atau memadukan pengetahuan yang telah dipelajarinya dalam rangkaian kalimat atau katakata yang tersusun secara baik.

Penelitian ini bertujuan untuk meningkatkan hasil belajar siswa pada mata pelajaran Pendidikan Agama Islam, dan sangat tepat menggunakan model penlitian tindakan kelas. Metode Permainan Bendera surat-surat pendek yang digunakan dalam Analisis pelaksanaan pembelajaran. Lembar observasi pelaksanaan pembelajaran yang berupa aktifitas guru dan aktifitas siswa, catatan lapangan dianalisis secara deskriptif setiap siklus merupakan data pelaksanaan pembelajaran. Yang dimaksud dengan analisis deskriptif adalah usaha melukiskan dan menganalisis kelompok yang diberikan tanpa membuat atau menarik kesimpulan dari populasi lebih besar. Menurut Sudjana dalam Anegawati (2016). Untuk rencana perbaikan pembelajaran pada siklus berikutnya hal ini sangat bermanfaat. Permainan Bendera dari hasil pengamatan kolaborator dari keterlaksanaan tahapan-tahapan Permainan Bendera dan 
catatancatatan dari kolaborator untuk acuan refleksi yang digunakan dalam menentukan keberhasilan pembelajaran.

\section{HASIL DAN PEMBAHASAN \\ Siklus I \\ Perencanaan}

Kegiatan yang dimulai dari tahap perencanaan Siklus I adalah sebagai berikut. 1. Membuat perencanaan pembelajaran yang terdiri dari Silabus dan RPP; 2. Merancang langkah-langkah pembelajaran atau metode yang akan dilaksanakan dalam pembelajaran; 3 . Membuat instrumen monitoring untuk mengamati aktifitas guru dan siswa didalam kelas selama proses pembelajaran; 4. Menyiapkan media atau instrumen, serta sarana pembelajaran yaitu Bendera surat An-Nasr dan surat Al-Ashr; kemdudian 5. Membuat instrumen evaluasi untuk meengukur tingkat hasil belajar pada siswa di evaluasi awal dan dilanjutkan nantinya pada evaluasi akhir yang dilaksanakan disetiap siklus. Adapun pada pelaksanaan Siklus I ini, Kompetensi Dasar yang ingin dicapai dengan menggunakan Instrumen Permainan Bendera adalah menghafal surat An-Nasr dan surat Al'Ashr.

\section{Tindakan/Pelaksanaan}

Pada pelaksanaan Siklus I digunakanlah pembelajaran Permainan Bendera surat An-Nasr dengan cara berikut: Guru meberikan motivasi kepada siswa dengan menanyakan apakah mereka sudah mengenal dan mendengar tentang surat-surat pendek yang terdapat dalam Al-Qur'an atau mereka sudah hafal dengan surat At Takasur. Siswa yang hafal, diberi kesempatan untuk menunjukkan hasil hafalannya kepada siswa yang lain. Pada pertemuan pertama di Siklus I, guru meminta dan sekaligus membantu mengelompokkan siswa menjadi 5 kelompok agar mempermudah siswa dalam menghafal. Guru menujukkan contoh bacaan surat An Nasr, siswa menirukan dan diulang-ulang sampai tiga kali. Guru menunjukkan media Bendera surat An-Nasr yang berjumlah tiga Bendera yang memuat masing-masing 1 ayat. Kemudian guru meminta perwakilan dari anggota kelompok satu, anggota kelompok dua dan anggota kelompok tiga maju kedepan untuk mengambil Bendera satu anggota kelompok. Pelaksanaannya siswa maju semua berebut untuk mengambil Bendera. Kemudian guru menjelaskan bahwa yang maju satu kelompok hanya satu orang, anggota yang lain duduk di kursi masing-masing untuk membaca urutan Bendera surat An-Nasr. Guru memanggil satu orang dari kelompok satu, dua, dan tiga untuk maju kedepan agar dapat memegang Bendera, kemudian membantu mengurutkan sesuai dengan urutan ayat benar.

Kemudian perwakilan dari masing-masing kelompok memegang dan membacakan ayat yang ada di Bendera dan diikuti oleh semua siswa didalam kelas. Kemudian, guru memberikan surat An-Nasr yang kembali dibagi menjadi tiga Bendera, agar siswa dapat menyusunnya di meja sehingga urutannnya menjadi benar. Ternyata ditemukan sejumlah kelompok yang penyusunan urutannya masih salah. Siswa diberi tugas menghafalkan untuk semua anggota kelompok masingmasing. Bagi siswa yang telah hafal guru akan meminta mereka untuk membantu menjadi tutor sebaya dikelompoknya. Pada pelaksanaan Siklus I, siswa telah melaksanakan tugas-tugas yang diberikan oleh guru. Tahap Observasi masih ditemukan siswa yang acuh terhadap tugas yang diberikan, ada yang asyik bermainmain, ada yang sibuk mengobrol, bahkan ada yang menolak untuk diajari oleh temannya yang sudah hafal. Guru kemudian mendatangi kelompok-kelompok yang masih belum mau mengikuti pelajaran dengan serius untuk memberikan pengarahan, penjelasan dan bimbingan. Selama 2 jam penelitian dan pelajaran berlangsung, hanya dua siswa yang sudah dapat menghafal. Akhirnya, kegiatan hafalan akan dilanjutkan dalam pertemuan kedua. Pada tahap Refleski Guru mengecek kesiapan siswa dalam menghafal surat AnNasr dengan cara menghafal bersama-sama. Setelah itu siswa menghafal dengan kelompok masing-masing, anggota kelompok yang sudah hafal mengajari anggota kelompoknya yang belum hafal. Setelah itu siswa menghafal satu persatu, guru mencatat kemampuan siswa dalam menghafal sambil memberikan bimbingannya terutama pada siswa yang belum hafal bacaan surah An-Nasr. Siswa yang mendapat nilai tertinggi diberikan penghargaan atau hadiah. Hal ini dilakukan untuk meningkatkan motivasi agar siswa lebih giat belajar.

\section{Siklus II}

Pada Siklus II, pembelajaran yang dilakukan pada mata pelajaran Pendidikan Agama Islam, adalah pembelajaran dengan kompetensi dasar menghafal AlQur'an surat An-Ashr dengan lancar, pertemuan dilaksanakansebanyak 2x (4 jam pelajaran) dengan langkah-langkah sebagai berikut:

\section{Perencanaan}

Tindakan yang akan dikerjakan di Siklus II ini masih tetap akan melakukan tindakan utama seperti pada Siklus I. Pada Siklus II ada beberapa hal yang akan dilakukan untuk memperbaiki kekurangan-kekurangan pada Siklus I. Adapun perubahan yang diperbaiki pada Siklus II antara lain sebagai berikut: 1. guru mengoptimalkan cara memotivasi siswa dalam menghafal; 2. guru memberikan bimbingan kepada kelompok maupun individu secara merata; 3. guru melakukan bimbingan dan dorongan kepada siswa agar dapat menghafal dengan maksimal; dan 4. guru menambahkan alokasi waktu untuk menghafal dengan mengubah jadwal yang harinya berurutan. 


\section{Tindakan/Pelaksanaan}

Pada awal memulai pelajaran, guru menyampaikan kepada siswa tujuan pembelajaran yang akan dicapai, dimana tujuan itu adalah agar siswa hafal surat Al-Ashr dengan lancar dan benar. Guru memotivasi siswa untuk menguasai materi hafalan surat Al-Ashr agar dapat digunakan dalam mengerjakan sholat. Guru membentuk kelompok siswa menjadi 5 kelompok. Dalam pembelajaran yang dibantu dengan instrumen Permainan Bendera surat Al-Ashr ini, mempermudah siswa dalam menghafal. Pelaksanaan Siklus II pada pertemuan ini berdasarkan hasil pengamatan telah berjalan sesuai yang direncanakan. Langkah-langkah pembelajaran sebagai berikut: Guru menunjukkan contoh bacaan surat Al-Ashr, siswa menirukan dan diulang-ulang sampai tiga kali. Guru menunjukkan Permainan Bendera surat Al-Ashr yang dibagi menjadi tiga Bendera yang masing-masing memliki satu ayat. Guru menunjuk perwakilan kelompok satu dua dan tiga untuk mengambil salah satu Bendera, tapi siswa maju semua berebut untuk mengambil Bendera. Kemudian guru menjelaskan bahwa yang maju, satu kelompok satu, anggota yang lain duduk dikursi masing-masing untuk membaca urutan Bendera sesuai urutan ayat surat Al-Ashr. Guru kembali menunjuk salah satu perwakilan dari kelompok satu, dua, dan tiga untuk maju ke depan mengambil satu Bendera kemudian diurutkan sesuai urutan ayat surat Al-Ashr. Apabila urutannya sudah tepat, perwakilan dari masing-masingkelompok membacakan ayat yang ada diBendera yang mereka pegang dan diikuti oleh seluruh anggota kelompok. Kemudian dilanjutkan kelompok lain sampai selesai semua kelompok. Setelah itu guru menyerahkan Bendera surat Al-Ashr yang dibagi menjadi tiga ayat, agar disusun di meja masing-masing sesuai dengan urutannya. Ternyata masih ditemukan kelompok yang belum tepat alam mengurutkannya. Tiap-tiap kelompok diberi tugas menghafal dengan anggota kelompoknya masing-masing.

Bagi siswa yang telah hafal, mereka diberikan tugas untuk membantu menjadi tutor sebaya dikelompoknya. Siswa telah melaksanakan tugas-tugas yang diberikan oleh guru. Tugas yang diberikan masih ditemukan beberapa siswa yang masih acuh. Masih ada yang mengobrol dengan temannya dan ada juga yang menolak ketika temannya mau membantu mengajarkan bagi yang belum hafal. Dalam pembelajaran, untuk memberikan pengarahan penjelasan dan bimbingan, guru mendekati kelompok yang masih belum serius. Baru 10 siswa yang mampu menghafal dengan lancar dan benar selama 2 jam pelajaran siswa belum bisa menghafal dengan benar dan lancar, sehingga hafalan akan dilanjutkan pada pertemuan kedua. Guru mengecek daftar kehadiran untuk mengetahui siswa yang tidak hadir pada hari itu pada pertemuan kedua Siklus II, kesiapan siswa dalam menghafal surat Al-Ashr dengan cara menghafal bersama-sama guru selalu mengecek.
Kemudian siswa menghafal dengan kelompok masingmasing, anggota kelompok yang sudah hafal mengajari anggota kelompok yang belum hafal. Siswa menghafal satu persatu, guru mencatat kemampuan siswa dalam menghafal sambil memberikan bimbingan terutama pada siswa yang belum kesulitan dalam menhafal. Akan diberikan penghargaan atau hadiah bagi siswa yang mendapat nilai tertinggi, hal ini dilakukan untuk meningkatkan motivasi agar siswa lebih giat belajar.

\section{Pembahasan}

Siswa telah melaksanakan tugas-tugas yang diberikan oleh guru pada pelaksanaan Siklus I. Masih terlihat ada siswa yang acuh terhadap tugas yang diberikan, ada yang asyik bermain-main, ada yang sibuk mengobrol, bahkan ada yang menolak untuk diajari oleh temannya yang sudah hafal. Kelompok-kelompok yang masih belum mau mengikuti pelajaran dengan serius untuk memberikan pengarahan, penjelasan dan bimbingan guru akan mendatangi satu persatu. Hanya dua siswa yang sudah dapat menghafal selama 2 jam penelitian dan pelajaran berlangsung, Akhirnya, kegiatan hafalan akan dilanjutkan dalam pertemuan kedua. Kesiapan siswa dalam menghafal surat An-Nasr dengan cara menghafal bersama-sama akan di cek oleh gurunya. Kemudian siswa menghafal dengan kelompok masingmasing, anggota kelompok yang sudah hafal mengajari anggota kelompoknya yang belum hafal. Setelah itu siswa menghafal satu persatu, guru mencatat kemampuan siswa dalam menghafal sambil memberikan bimbingannya terutama kepada siswa yang belum mampu menghafal bacaan surah An-Nasr. Akan diberikan penghargaan atau hadiah bagi siswa yang mendapat nilai tertinggi, dilakukan untuk meningkatkan motivasi agar siswa lebih giat belajar. Aktifitas guru saat kegiatan pembelajaran Pendidikan Agama Islam dengan Permainan Bendera di Siklus I berlangsung, berdasarkan hasil pengamatan masih ditemukan beberapa kekurangan, berdasarkan hasil pengamatan. yaitu: 1 . Siswa yang masih belum hafal surat An-Nasr masih ditemukan pada saat materi disampaikan guru, masih kurang begitu jelas dan tepat dalam menyampaikan arahan ; 2. Dalam memberikan bimbingan kepada kelompok guru belum tepat sasaran hal ini disebabkan ketika guru membimbing kelompok tertentu, kelompok lain masih ada yang ribut; 3. Sebelum kerja kelompok dilaksanakan guru masih kurang dalam memberikan arahan kerja kelompok; 4. Bimbingan secara maksimal untuk semua kelompok masih kurang dilaksanakan oleh guru. 5. Guru masih kurang memperhatikan kelompokkelompok yang belum lancar membaca dan 6 . Bimbingan pada kelompok yang sering bermain-main guru masih kurang memberikan perhatian. Penggunaan Permainan Bendera surat An-Nasr pada Siklus I secara umum masuk dalam katagori baik terhadap aktifitas siswa dalam kegiatan pembelajaran. 
Masih terdapat beberapa kegiatan siswa yang belum terlaksana secara optimal dan tepat sasaran, seperti: 1. Pembagian kelompok yang kurang merata dikarenakan Tutor sebaya belum berjalan dengan lancar; 2. Siswa belum lancar dalam membaca sehingga terlalu fokus dan bersemangat dalam membaca ; 3 . Suara siswa terdengar sangat pelan pada saat membaca yang berakibat siswa lain mengalami kesulitan mendengarnya; 4. Dari teman satu kelompoknya yang hafal masih ada beberapa siswa yang belum hafal tetapi tidak mau menerima bantuan dari temannya. dan 5 . Siswa yang belum mau menghafal dan memilih bermain atau memukul-mukul meja masih ditemukan. Hasil pembelajaran Pada Siklus I, hasil pembelajaran ditemukan sebagai berikut: $20 \%$ terdapat siswa yang sangat hafal, $25 \%$ siswa yang hafal, $40 \%$ terdapat siswa yang kurang hafal, dan $15 \%$ siswa yang tidak hafal. Dari hasil tes yang dilaksanakan masih ditemui siswa yang belum hafal. Siswa yang belum hafal disebabkan oleh belum lancarnya siswa dalam membaca surat An-Nasr terdapat pada hasil observasi. Jadwal pelajaran Pendidikan Agama Islam untuk siswa Kelas I selain daripada itu, disusun secara berurutan tanpa memberikan jeda, menyebabkan siswa mengalami kesulitan jika mereka berlatih menghafal di rumah masing-masing. Pada Siklus I berdasarkan kekurangan-kekurangan dan permsalahan yang mumcul, maka pada Siklus II kegiatan pembelajaran diperlukan beberapa perubahan yaitu: 1 . Cara memotivasi siswa dalam menghafal harus dioptimalkan oleh guru, 2. Kepada kelompok maupun individu secara merata diberikan bimbingan oleh guru 3. Bimbingan dan dorongan kepada siswa untuk menghafal dengan maksimal dilakukan oleh guru dan 4. guru menambah alokasi waktu untuk berlatih ditambahkan oleh guru dalam mengubah jadwal yang berurutan. Siswa lebih bersemangat dan lebih aktif dan saling berkompetisi secara sehat untuk dapat menyelesaikan tugas dengan tepat waktu terdapat pada aktivitas Siklus II. Secara individu dari permainan tersebut siswa dapat dengan mudah menghafal surat-surat pendek dikarenakan telah berulang kali dibaca didengar dan diberi kesempatan untuk menghafal. Rasa senang dan bersemangat untuk menghafal ditemui pada pembelajaran melalui Permainan Bendera. Pembelajaran yang mengaktifkan siswa baik dengan permainan telah dilakukan oleh guru dalam mengembangkan konsep atau hafalan surat. Terlihat adanya peningkatan yang diperoleh dari hasil belajar dari Siklus I dan II. Pada Siklus II, hasil pembelajaran ditemukan hasil sebagai berikut: $65 \%$, siswa yang sangat hafal, $30 \%$ siswa yang hafal, $5 \%$ siswa yang kurang hafal, $0 \%$ siswa yang tidak hafal. Terdapat peningkatan yang sangat signifikan yang ditunjukkan pada hasil, karena jumlah siswa yang tidak hafal adalah $0 \%$ dimana pada Siklus I mencapai $16 \%$. Aktifitas guru secara umum dari hasil pengamatan terhadap pelaksanaan aktifitas guru dalam pelaksanaan pembelajaran Permainan Bendera telah berjalan baik.
Terhadap siswa bisa dikatakan sukses dilihat dari hasil penelitian.

\section{SIMPULAN}

Pelaksanaan penelitian tindakan kelas melalui Permainan Bendera berdasarkan analisis data mengenai surat-surat pendek disimpulkan siswa dalam kegiatan pembelajaran menjadi lebih bersemangat dan lebih aktif dan saling berkompetisi secara sehat untuk dapat menyelesaikan tugas dengan tepat waktu. Dari permainan tersebut siswa dapat dengan mudah menghafal surat-surat pendek dikarenakan telah berulang kali dibaca didengar dan diberi kesempatan untuk menghafal secara individu. Instrumen Permainan Bendera juga menciptakan kegiatan pembelajaran yang tidak membosankan. Hasil pembelajaran Pendidikan Agama Islam untuk Siklus Iterdapat 20\% sangat hafal (sangat baik) dan 25\% hafal (baik) jumlah keseluruhan yang sangat hafal dan $45 \%$ hafal (baik) Siklus I. Untuk Siklus II terdapat 65\% sangat hafal (sangat baik) dan $30 \%$ yang hafal (baik) jumlah keseluruhan yang sangat hafal dan 95\% hafal. Adanya peningkatan hasil belajar pada hasil penelitian ini menunjukkan Pendidikan Agama Islam melalui metode Permainan Bendera untuk Siklus I 45\% siswa hafal ayat-ayat pendek dan Siklus II 95\% siswa hafal.

Dalam melakukan pembelajaran guru diharapkan untuk melakukan metode Permainan Bendera, untuk pembelajaran Pendidikan Agama Islam untuk kelas I. Dalam mengembangkan pembelajaran guru diharapkan mengembangkan pembelajaran yang inovatif, kreatif, interaktif, dan menyenangkan. Sekolah diharapkan dapat menganjurkan atau mendorong para guru untuk mengembangkan pembelajaran yang inovatif, kreatif, interaktif, dan menyenangkan. Sekolah memberikan fasilitas, baik fisik maupun pengetahuan melalui nara sumber atau bentuk pelatihan yang lainnya. Dan pagi peneliti lain bisa menjadikan jurnal sebagai bahan referensi atau menjadi acuan untuk pengembangan penelitian menggunakan metode ini ketingkat lebih lanjut.

\section{DAFTAR PUSTAKA}

Al Fatihah, M. (2016). Hubungan antar Kemandirian Belajar dengan Prestasi Belajar PAI Siswa Kelas III SDN Panular Surakarta. Jurnal At-Tanbawi. Volume 1, No. 2, Juli-Desember 2016. 197-207.

Anegawati, E. (2016). Penerapan Strategi Pemebelajaran Modelling The Way untuk Meningkatkan Hasil Belajar Pendidikan Agama Islam (PAI) Siswa Kelas IV SD Negeri 010 Banjar Panjang Kecamatan Kerumutan. Jurnal Primary Program Studi Pendidikan Guru Sekolah Dasar. Fakultas Keguruan dan Ilmu Pendidikan Universitas Riau. Volume 5, Nomor 3, Edisi Khusus HUT PGRI Ke-71. 618-632 
Ayudia, Suryanto, E., Waluyo, B. (2016). Analisis Kesalahan Penggunaan Bahasa Indonesia dalam Laporan Hasil Observasi pada Siswa SMP.BASASTRA. Jurnal Penelitian Bahasa, Sastra Indonesa dan Pengajarannya. Volume 4, Nomor 1, April 2016. 36-49

Dananjaya, U. (2012). Media Pembelajaran Aktif. Bandung: Nuansa Cendekia

Nuansa Freeman, J., Munandar, U. (1996). Cerdas dan Cemerlang: Kiat Menemukan dan Mengembangkan Bakat Anak 0-5 Tahun. Jakarta: Gramedia Pustaka Utama.

Nurlina, dkk. (2014). Implementasi Manajemen Pengajaran PAI untuk Meningkatkan Prestasi Belajar Siswa pad SDN Ateuk Kabupaten Aceh Besar. Jurnal Mudarrisuna. Vol. 4, No. 1. 124135

Nurmayanti, A., Mardhiah, I., Rachmat, N. (2017). Pemanfaatan Internet dalam Meningkatkan Hasil Belajar PAI Siswa (Studi Kasus Siswa Kelas X SMK Negeri 7 Jakarta Timur). Jurnal Studi AlQur'an: Membangun Tradisi Berfikir Qur'ani. Vol. 13, No.1. 48-60.

Piaget, J. (1951). The Child's Conception of The World. Maryland: Littlefield Publishers.

Sulasmi. (2014). Peningkatan Hasil Belajar Pendidikan Agama Islam melalui Games Bendera Kelas I.1 SD Negeri Keputran "A". Jurnal Ilmiah Guru "COPE". No. 01/Tahun XVIII. 19-25. 